\title{
Ligands of peroxisome proliferator-activated receptor- $\gamma$ increase the generation of vascular endothelial growth factor in vascular smooth muscle cells and in macrophages ${ }^{*}$
}

\author{
Alicja Jozkowicz ${ }^{1 凶}$, Jozef Dulak ${ }^{2}$, Ewa Piatkowska ${ }^{1}$, Wojciech Placha ${ }^{3}$ and \\ Aldona Dembinska-Kiec ${ }^{1}$ \\ ${ }^{1}$ Department of Clinical Biochemistry, and ${ }^{3}$ Department of Medical Biochemistry, Collegium \\ Medicum, Jagiellonian University, Krakow, Poland; ${ }^{2}$ Department of Cardiology, Innsbruck \\ University, Innsbruck, Austria
}

Received: 25 September, 2000; accepted: 25 October, 2000

Key words: peroxisome proliferator-activated receptor- $\gamma$, vascular endothelial growth factor, ciglitazone, prostaglandin- $\mathrm{J}_{2}$, thiazolidinediones, angiogenesis

\begin{abstract}
Peroxisome proliferator-activated receptors- $\gamma$ (PPAR $\gamma)$ are ligand-inducible transcription factors of the nuclear hormone receptor superfamily. We examined the effect of PPAR $\gamma$ activation on the generation of vascular endothelial growth factor (VEGF), one of the major angiogenic agents. Rat vascular smooth muscle cells (VSMC) and murine macrophages RAW264.7 were incubated for $24 \mathrm{~h}$ with PPAR $\gamma$ activators: prostaglandin $\mathrm{J}_{2}$ and ciglitazone. PPAR $\gamma$ were expressed in VSMC and RAW cells and their activity was upregulated in the presence of $\mathrm{PGJ}_{2}$ and ciglitazone. Incubation of the cells with PPAR $\gamma$ activators significantly augmented the release of VEGF protein into the media, both in resting and in IL-1 $\beta$ - or LPS-stimulated cultures. The higher protein generation was connected with the increased expression of mRNA and
\end{abstract}

\footnotetext{
$\overline{{ }^{*}}$ The study was supported by research grants from the State Committee for Scientific Research, Poland (KBN 4 PO5A 10817 and 4 PO5A 131 14), and by grant from Jagiellonian University (501/PKL/114/L).

${ }^{\bowtie}$ Corresponding author: Alicja Jozkowicz, Department of Vascular Surgery, AKH, University of Vienna, Waehringer Guertel 18-20, Vienna, A-1090 Austria; tel. (43 1) 40400 6792; fax (43 1) 40400 6782; e-mail: alicia.jozkowicz@akh-wien.ac.at
}

Abbreviations: AP-1, activating protein-1; AP-2, activating protein-2; GAPDH, glyceraldehyde phosphate dehydrogenase; FCS, fetal calf serum; HIF-1, hypoxia responsive element-1; IL-1 $\beta$, interleukin- $1 \beta$; IL-6, interleukin-6; LDH, lactate dehydrogenase; LPS, lipopolysaccharide; MCP-1, monocyte chemoatractant protein-1; $\mathrm{PGJ}_{2}$, prostaglandin- $\mathrm{J}_{2}$; PPAR, peroxisome proliferator-activated receptor; PPRE, PPAR responsive element; RANTES, regulated on activation, normal T expressed and secreted; RZR, retinoid Z receptor; RXR, retinoid X receptor; SP-1, stimulatory protein-1; TNF- $\alpha$, tumor necrosis factor- $\alpha$; TZD, thiazolidinediones; VEGF, vascular endothelial growth factor; VSMC, vascular smooth muscle cells. 
transcriptional activation of VEGF promoter. We conclude that the activation of PPAR $\gamma$ upregulates the generation of VEGF and may be involved in the regulation of angiogenesis.

Peroxisome proliferator-activated receptors (PPARs) are ligand-inducible transcription factors that belong to the nuclear hormone receptor superfamily, together with receptors for the thyroid hormone, retinoids, steroid hormones and vitamin D [1]. In mammals, the PPAR family consists of three subtypes of proteins encoded by separate genes: PPAR $\alpha$, PPAR $\gamma$, and PPAR $\delta$. They act as heterodimers with the retinoid X receptor (RXR) and regulate gene transcription by binding to specific response elements (peroxisome proliferator response element, PPRE) in promoters of the target genes [1-3].

Activation of PPAR $\alpha$ governs the rate of fatty acid uptake, esterification into triglyceride or oxidation $[2,4,5]$. PPAR $\gamma$ is involved in adipocyte differentiation and regulation of fat storage [2, 3, 5] as well as in the maintenance of glucose homeostasis and insulin signaling pathway [3, 6]. PPARs also participate in the down-regulation of inflammatory response. Finally, there is a growing body of evidence that PPAR $\gamma$ ligands can inhibit the progression of colon or breast cancers in some experimental models, bringing about differentiation or apoptosis of tumor cells [7-9].

Major endogenous PPAR ligands are fatty acids and their derivatives, while synthetic PPAR activators include the peroxisome proliferators and non-steroid anti-inflammatory agents. Exogenous PPAR $\gamma$ inducers comprise thiazolidinediones (TZD), well known insulin-sensitizing compounds [1]. TZD efficiently reduces hyperinsulinemia, hyperglycemia, and hypertriglyceridemia as well as decreases high blood pressure, and thereby ameliorates diabetic complications [6, 10]. Two TZD agents, rosiglitazone and troglitazone, were approved for the treatment of insulin-resistance in type II diabetes in humans [1]. As diabetes represents a disease with numerous vascular complications, it is essential to scrutinize the eventual involvement of PPAR $\gamma$ acti- vation in the generation of growth factors responsible for angiogenesis and maintenance of vasculature.

Angiogenesis involves the proliferation of endothelial cells from pre-existing capillaries, the breakdown and reassembly of the extracellular matrix and the morphogenic process of endothelial tube formation [11, 12]. A fundamental regulator of normal and pathological angiogenesis is vascular endothelial growth factor (VEGF) produced by many types of cells in response to hypoxia, hypoglycemia or some pro-inflammatory cytokines. The demonstration that VEGF generation is higher in the retina and vitreous body of patients with ischemic retinopathies [13-16] and evidences that VEGF antagonists may inhibit retinal or iris neovascularization in animal models [17-19] indicates that VEGF is a potent mediator of retinal angiogenesis in diabetes [20]. It has been reported recently that TZD-mediated $\mathrm{PPAR} \gamma$ activation may antagonize the VEGF activity by downregulation of the expression of VEGF receptors in endothelial cells [21] or by inducing endothelial cell apoptosis [22]. However, the involvement of TZD drugs in the regulation of generation of VEGF protein has not been studied yet.

In this paper, we examined the effect of PPAR $\gamma$ activation on the generation of VEGF in vascular smooth muscle cells (VSMC) and macrophages. Our results demonstrate that the generation of VEGF is increased by PPAR $\gamma$ ligands.

\section{MATERIALS AND METHODS}

Chemicals. PPAR $\gamma$ ligands, ciglitazone and 15-deoxyprostaglandin- $\mathrm{J}_{2}\left(\mathrm{PGJ}_{2}\right)$, were from Biomol, interleukin- $1 \beta$ (IL-1 $\beta$ ) and lipopolysaccharide (LPS) were purchased from Sigma, culture media (DMEM F-12, 
RPMI-1641) and fetal calf serum (FCS) were from Gibco. Tfx-50 liposomes and lactate dehydrogenase (LDH) release kit were bought from Promega and QIAfilter maxiprep kit from Qiagen. The ELISA kit for mouse VEGF was from R\&D and the kit for measurement of luciferase activity was purchased from Roche Diagnostic.

Cell culture. Murine macrophage-like cells RAW264.7 were cultured in RPMI-1641 medium supplemented with $10 \%$ FCS. Vascular smooth muscle cells (VSMC) were isolated by collagenase digestion of thoracic rat aorta and cultured in DMEM F-12 medium supplemented with $5 \%$ FCS. VSMC of 5th to 10th passages were used for experiments. VSMC or RAW were seeded in 24-well plates and grown to confluency. Before experiments, the cells were starved overnight in a medium containing $0.5 \%$ FCS. Then, the medium was replaced with the fresh FCS and cells were supplemented with PPAR activators: ciglitazone $(0.3-10 \mu \mathrm{M})$ or $\mathrm{PGJ}_{2}(0.1-10 \mu \mathrm{M})$. Four hours later, some VSMC and RAW were additionally stimulated with IL-1 $\beta$ ( $5 \mathrm{ng} / \mathrm{ml}$ ) or LPS (100 ng/ml), respectively. After $24 \mathrm{~h}$, the culture media were collected and concentrations of VEGF were measured by ELISA, while cell viability was assessed by colorimetric measurement of LDH levels.

$\boldsymbol{R T}$-PCR. After removed of culture medium, total RNA was isolated from the cells by acid guanidinium thiocyanate-phenol-chloroform extraction [23]. RT-PCR reactions were performed on $100 \mathrm{ng}$ of RNA with primers recognizing PPAR $\gamma$ (5'-TCT CTC CGT AAT GGA AGA CC and 5'-GCA TTA TGA GCA TCC CCA C) or VEGF (5'-CAC CGC CTC GGC TTG TCA CAT and 5'-CTG CTG TCT TGG GTG CAT TGG). The amplifications of the housekeeping GAPDH gene were made as an internal control. RT-PCR was carried out for $40 \mathrm{~min}$ at $65^{\circ} \mathrm{C}$ with Tth polymerase $(2.5 \mathrm{U} / 10 \mu \mathrm{l})$ in the presence of $\mathrm{Mn}^{2+}(2.5 \mathrm{mM})$. After the addition of chelating buffer (EGTA $750 \mu \mathrm{M}, \mathrm{Mg}^{2+} 2.5$ $\mathrm{mM}$; total volume of PCR mixture $-50 \mu \mathrm{l}$ ), the
PCR was performed for 35 cycles at $94^{\circ} \mathrm{C}-40$ $\mathrm{s}, 58^{\circ} \mathrm{C}-40 \mathrm{~s}$, and $72^{\circ} \mathrm{C}-50 \mathrm{~s}$ profile. PCR products were analyzed by agarose gel electrophoresis.

Transient transfection assay. To confirm the transcriptional activity of PPAR in the studied cells, VSMC and RAW macrophages were transfected with reporter plasmid pGL3 containing three copies of PPAR-responsive element (PPRE) which regulated luciferase gene expression (construct was a kind gift by Dr. Lluis Fajas, France). To check the transcriptional regulation of VEGF promoter activity, we used the human VEGF gene promoter $(-2279$ to +54$)$ cloned into luciferase reporter plasmid pGL2 (construct was a kind gift by Dr. Hideo Kimura, Japan). Plasmids were amplified in HB101 E. coli and isolated using QIAfilter maxiprep. RAW and VSMC grown to $70-80 \%$ confluence were transfected in 24-well plates using $1.5 \mu \mathrm{l}$ Tfx-50 liposomes and $0.5 \mu \mathrm{g}$ plasmid DNA per well, according to the vendor's protocol. After $24 \mathrm{~h}$, the medium was refreshed and, where necessary, supplemented with ciglitazone $(3 \mu \mathrm{M})$, or $\mathrm{PGJ}_{2}$ (3 $\mu \mathrm{M})$. The cells were collected $48 \mathrm{~h}$ later, lysed and subjected to luciferase assay.

Statistical analysis. All experiments were repeated 3-7 times, in duplicate or triplicate. Data are presented as means \pm S.D. Statistical comparison were made by Student's $t$-test or by ANOVA followed by Tukey test.

\section{RESULTS}

\section{Expression and transcriptional activity of PPAR $\gamma$}

Expression of PPAR $y$ in the studied cells was confirmed by RT-PCR analysis. The presence of PPAR $\gamma$ mRNA was detected both in VSMC and in RAW (Fig. 1, insert). Both in VSMC and RAW cells transfected with reporter plasmid, PPAR $\gamma$ ligands significantly increased the PPRE-driven luciferase activity 
(Fig. 1). The obtained results imply that PPAR $\gamma$ is an active transcription factor both in macrophages and VSMC.

Neither ciglitazone $(0.3-10 \mu \mathrm{M})$ nor $\mathrm{PGJ}_{2}$ (0.1-10 $\mu \mathrm{M})$ influenced the viability of VSMC and RAW, as determined by LDH-release test. Increased toxicity was detected only in RAW incubated with the highest dose of $\mathrm{PGJ}_{2}$ (data not shown).

\section{Effect of PPAR $\gamma$ ligands on the generation of VEGF protein}

To determine the effect of PPAR $\gamma$ ligands on VEGF release from the studied cells, the con- in a potent upregulation of VEGF generation and this influence was even stronger than in VSMC. PGJ ${ }_{2}$ also increased VEGF generation in RAW, although only the highest non-toxic concentration $(3 \mu \mathrm{M})$ was effective.

\section{Effect of PPAR $\gamma$ ligands on the expression of VEGF mRNA}

The expression of VEGF mRNA in the studied cells was confirmed by RT-PCR analysis. The presence of mRNAs for $\mathrm{VEGF}_{120}$ and VEGF $_{164}$ isoforms was regularly detected in VSMC (Fig. 4a). In RAW macrophage-like cells, a higher expression of $\mathrm{VEGF}_{120}$ was usu-

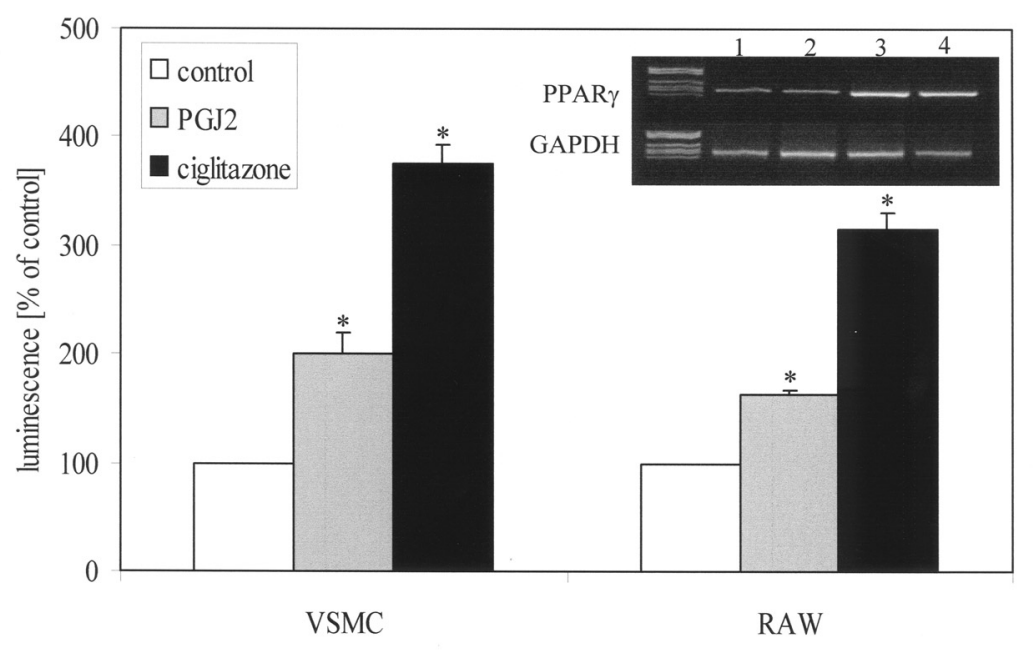

Figure 1. Representative of 3 similar experiments showing the effect of PPAR $\gamma$ ligands on the activity of PPRE measured by luciferase assay in transiently transfected VSMC or RAW.

${ }^{*} P<0.05$ in comparison to control cells (Student's $t$-test). Insert: typical results of RT-PCR reaction for PPAR $\gamma$ mRNA in control cells. Lanes 1, $2-$ VSMC, 3, 4 - RAW. centrations of VEGF protein in the culture media were measured by ELISA. After $24 \mathrm{~h}$ incubation, both types of cells released comparable amounts of VEGF protein, approximately $100-200 \mathrm{pg} / \mathrm{ml}$. IL- $1 \beta$ significantly increased the generation of VEGF in VSMC, while stimulation of RAW macrophages with LPS did not influence the VEGF synthesis (not shown).

In VSMC, ciglitazone $(3-10 \mu \mathrm{M})$ and $\mathrm{PGJ}_{2}$ $(0.1-10 \mu \mathrm{M})$ significantly increased the generation of VEGF both in resting and IL- $1 \beta$-stimulated cells (Fig. 2). A very similar effect of PPAR $\gamma$ ligands was also observed in resting or LPS-stimulated RAW macrophages (Fig. 3). Incubation of RAW with ciglitazone resulted ally observed (Fig. 4b). Both in VSMC and in RAW, the RT-PCR signal was stronger in cells incubated with ciglitazone or $\mathrm{PGJ}_{2}$ (Fig. 4).

\section{Effect of PPAR $\gamma$ ligands on the activity of VEGF gene promoter}

The cells were transfected with reporter plasmid containing the VEGF gene promoter and then incubated with ciglitazone or $\mathrm{PGJ}_{2}$. In VSMC, as well as in RAW macrophages, some basal activity of the VEGF promoter was observed, as determined by luciferase assay. In both cell types, the promoter activity was slightly but significantly enhanced by ciglitazone or $\mathrm{PGJ}_{2}$ (Fig. 5). These data indicate 


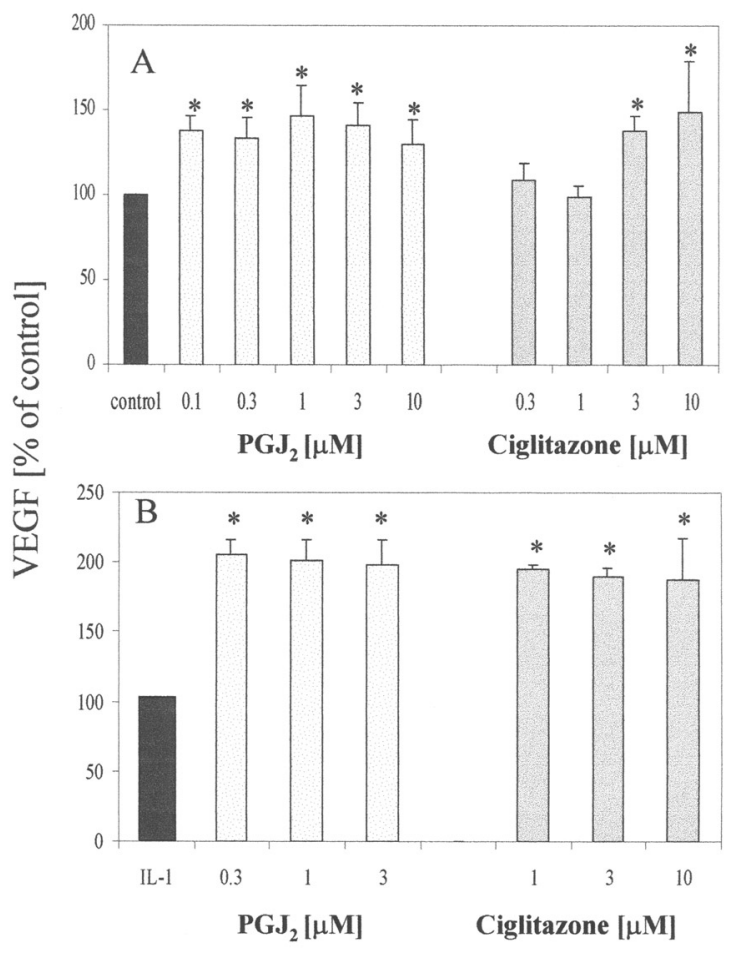

Figure 2. Effect of PPAR $\gamma$ ligands on VEGF protein level in the culture media after $24 \mathrm{~h}$ incubation of VSMC.

VEGF concentrations were measured by ELISA. Each bar represents mean \pm S.D. of $2-5$ experiments made in duplicate or triplicate and expressed as a percentage of the control value. A, VSMC incubated without IL- $1 \beta$ (control: intact cells); B, VSMC stimulated with IL-1 $\beta$ (control: cells incubated with IL- $1 \beta$ only). ${ }^{*} P<0.05$ in comparison to controls (ANOVA followed by Tukey test).

that the effect of PPAR $\gamma$ ligands on VEGF mRNA expression may be, in part, mediated by an increased transcription rate from the VEGF promoter.

\section{DISCUSSION}

We showed that PPAR $\gamma$ ligands increase the synthesis of VEGF, a major angiogenic factor. We used two, well-characterized PPAR $\gamma$ agonists, namely a metabolite of the eicosanoid prostaglandin- $\mathrm{J}_{2}$, which is the most potent natural ligand of PPAR $\gamma$ [1, 24], and ciglitazone (a TZD derivative), which is a highly specific exogenous PPAR $\gamma$ activator [1, 6].

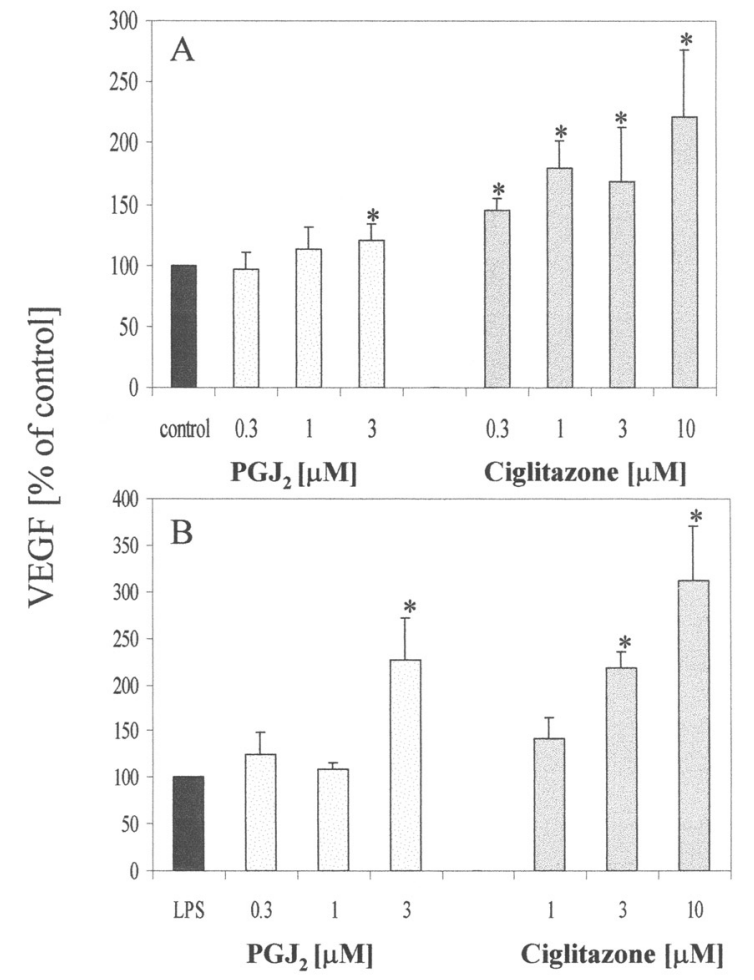

Figure 3. Effect of PPAR $\gamma$ ligands on VEGF protein level in the culture media after $24 \mathrm{~h}$ incubation of RAW.

VEGF concentrations were measured by ELISA. Each bar represents mean \pm S.D. of 3-4 experiments made in duplicate or triplicate and expressed as a percentage of the control value. A, RAW incubated without LPS (control: intact cells); B, RAW stimulated with LPS (control: cells incubated with LPS only). ${ }^{*} P<0.05$ in comparison to controls (ANOVA followed by Tukey test).

Both ligands effectively increased VEGF mRNA expression and protein release. Very recently, a similar finding was reported for human vascular smooth muscle cells [25]. The involvement of PPAR $\gamma$ activation in the upregulation of VEGF synthesis was also suggested in human monocyte cell line [26]. Our results fully confirm these reports and extend them, suggesting that the augmentation of VEGF protein synthesis is, in part, dependent on the increased activity of VEGF promoter.

So far, the expression of PPAR $\gamma$ was described in adipose tissues, liver, adrenal gland, spleen, skeletal muscles and retina [1]. High expression has also been detected in activated macrophages, including murine RAW 


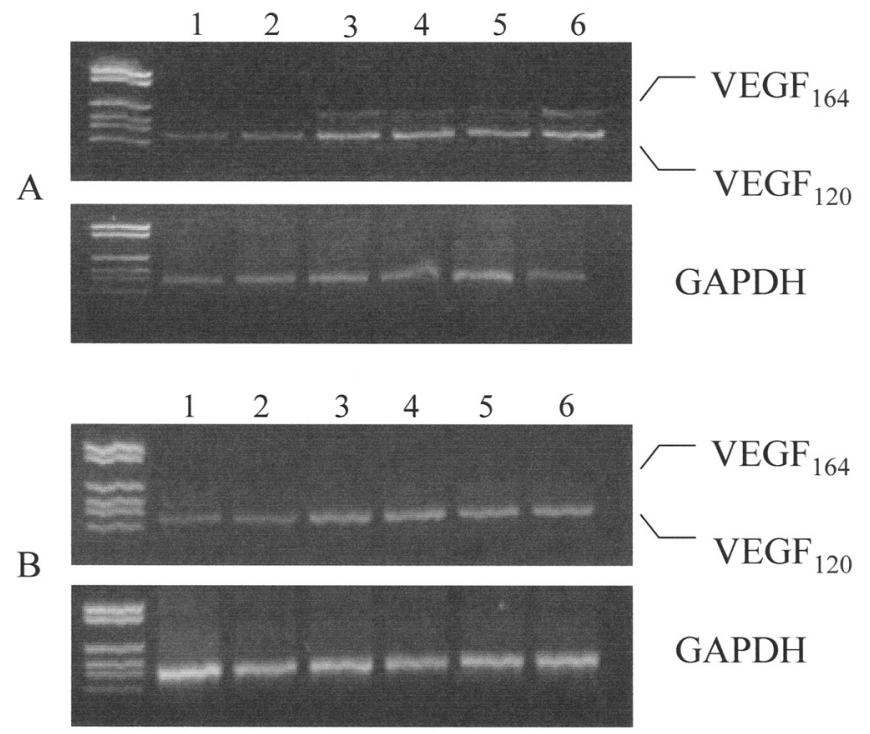

Figure 4. Representative results of RT-PCR reaction for VEGF mRNA in VSMC (A) and RAW macrophages (B).

Lanes 1, 2 - control, 3, $4-$ PGJ $_{2}$ ( $3 \mu \mathrm{M}), 5,6-$ ciglitazone $(3 \mu \mathrm{M})$. Note the stronger VEGF signal in the presence of PPAR $\gamma$ activators.

macrophage-like cells [1, 27, 28]. However, there were some doubts concerning the presence of functional PPAR $\gamma$ in VSMC [29]. Recently, Iijima and colleagues [30] reported the expression of PPAR $\gamma$ in rat aorta and rat VSMC cultured in vitro. In agreement with these findings, our data validate that PPAR $\gamma$ is an active transcription factor both in macrophages and in VSMC.

It has been established that activation of PPAR $\gamma$ in the vessel wall participate in down-regulation of inflammatory processes [31]. PPAR $\gamma$ ligands suppress the synthesis of metalloproteinases and pro-inflammatory cytokines, e.g. TNF $\alpha$, RANTES, MPC-1, IL-6 or IL-1 $\beta$ [32-35]. In vivo studies revealed that TZD substantially attenuates neointimal hyperplasia in an injury model in rats [10, 36]. Furthermore, a slow-down of atheromatous plaque progression was observed under TZD treatment in humans [1]. These effects may be related to the reduced inflammatory response [32-35] or to the inhibition of proliferation, migration and phenotyping modulation of VSMC [10, 37]. Our results, showing increased VEGF synthesis, add a new possible effect of PPAR $\gamma$ activation. VEGF can have a beneficial impact on the vessel wall by supporting endothelial cell survival and activity [11]. It may also inhibit intimal hyperplasia by promoting reendothelialization after arterial injury [12]. Additionally, VEGF activates the synthesis of nitric oxide in endothelial cells, resulting in the relaxation of the vessel wall and lower blood pressure [38, 39]. One can speculate that PPAR $\gamma$-mediated upregulation of VEGF production contributes to the hypotensive effect of TZD treatment [1, 40, 41].

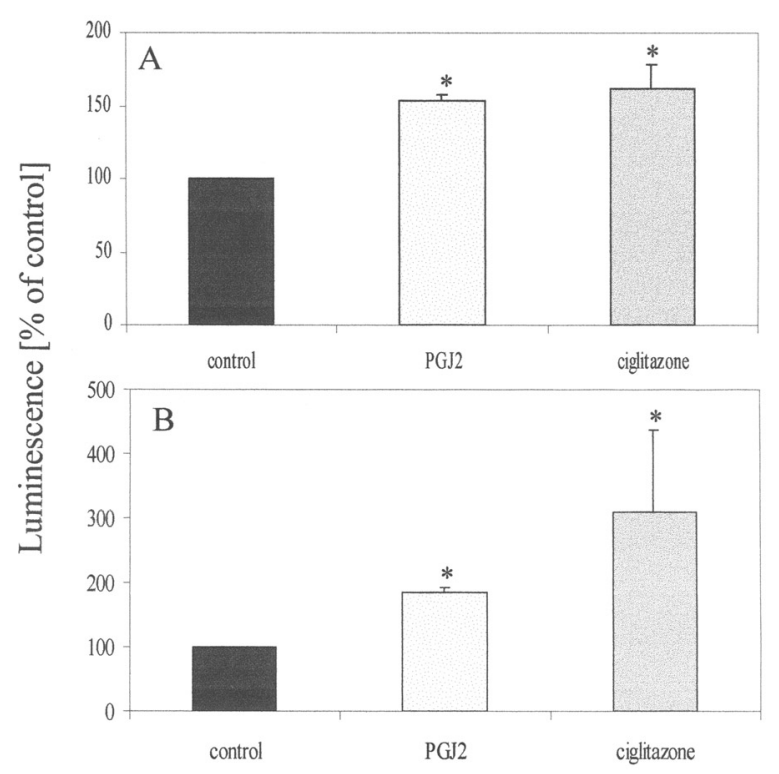

Figure 5. Effect of PPAR $\gamma$ ligands on the activity of VEGF gene promoter measured by luciferase assay in transiently transfected VSMC (A) or RAW (B).

Each bar represents a mean \pm S.D. of 3 experiments made in duplicate or triplicate and expressed as a percentage of the control value. ${ }^{*} P<0.05$ in comparison to control cells (Student's $t$-test). 
VEGF is produced in numerous ocular cells, including retinal pigment cells, pericytes, endothelial cells and glial cells [42]. Hypoxia-induced up-regulation of the expression of both VEGF and VEGF receptors is the major mediator of retinopathies [20,43]. Studies in transgenic mice evidenced that increased expression of VEGF in the retina is sufficient for retinal neovascularization, even in normoxic conditions [20]. Therefore, the effect of PPAR $\gamma$ activation on VEGF generation might be important in diabetic patients endangered with retinopathy and treated with insulin-sensitizing TZD.

Recently, two papers have reported that the activation of PPAR $\gamma$ in endothelial cells strongly inhibits VEGF-induced angiogenesis [21, 22]. High doses of $\mathrm{PGJ}_{2}$ or TZD inhibited the proliferation of endothelial cells and their differentiation into tube-like structures, dependent on the reduced expression of VEGFR1 and VEGF-R2 receptors [21]. Our data suggest, however, that the influence of PPAR $\gamma$ activation is pleiotropic and that the decrease in VEGF receptor expression in endothelial cells is accompanied by increased VEGF generation in VSMC or macrophages. The final outcome is difficult to predict and may depend on experimental models.

Ligand-activated PPAR $\gamma$ protein forms a heterodimer with RXR $\alpha$ and may directly regulate gene expression through PPRE region in the target gene promoter [1, 3, 4]. The VEGF gene promoter, however, does not contain the PPRE motif. Therefore, it seems that PPAR $\gamma$ ligands upregulate VEGF expression indirectly. Analysis of the VEGF gene promoter region reveals several potential binding sites for transcription factors activating protein-1 and -2 (AP-1, AP-2), stimulatory protein-1 (SP-1) and hypoxia responsive element-1 (HIF-1) [44]. Therefore, it is surprising that $\operatorname{PPAR} \gamma$, which is known to inhibit AP-1 activity [41], actually upregulates VEGF expression. On the other hand, AP-1 together with HIF-1 are the major factors responsible for hypoxia-induced generation of VEGF [44]. In normoxia, basal and cytokine-enhanced VEGF expression is mediated mostly by SP-1 protein, which interacts with four SP-1 binding sites located in the proximity of transcription start site $[45,46]$. There is no data concerning the mutual regulation of PPAR and SP-1. Some observations suggest, however, that these transcription factors may act synergistically and overexpression of PPAR or RXR may enhance the effect of SP-1 in the up-regulation of gene transcription [47]. This might be one of the possible explanations of PPAR $\gamma$-mediated upregulation of basal and cytokine-induced VEGF production.

TZDs, which are commonly accepted as highly specific ligands for PPAR $\gamma$, are also able to activate the RZR $\alpha$ nuclear receptor [48]. RZR $\alpha$ is involved in regulation of cellular differentiation, the inflammatory response, and lipid metabolism [48, 49]. VEGF gene promoter analysis shows the presence of two RZR consensus-like motifs (at -1834 and -167), one of them overlapping with the AP-1 binding site. Therefore, the involvement of RZR $\alpha$ transcription factor in ciglitazone-mediated upregulation of VEGF expression cannot be excluded.

Finally, it has been shown that PPAR $\gamma$ ligands upregulate the expression of the heme oxygenase-1 (HO-1) gene [50, 51]. In VSMC and macrophages, HO-1 activation significantly augmented the synthesis of VEGF [52]. Therefore, we can speculate that PPAR $\gamma$-induced HO-1 activity might contribute to the observed upregulation of VEGF production.

In summary, we show that both exogenous and endogenous ligands of PPAR $\gamma$ upregulate the generation of VEGF. Probably the increase in the synthesis of mRNA and protein depends in part on the activation of the VEGF promoter. Further examinations are necessary to determine the molecular mechanism underlying this effect.

The excellent technical assistance of Ms. Urszula Ciałowicz and Ms. Danuta Żmudzinska-Grochot is greatly acknowledged. 


\section{R E F E R E N C ES}

1. Michalik, L. \& Wahli, W. (1999) Peroxisome proliferator-activated receptors: Three isotypes for a multitude of functions. Curr. Opin. Biotechnol. 10, 564-570.

2. Motojima, K., Passilly, P., Peters, J.M. \& Gonzales, F.J. (1998) Expression of putative fatty acid transporter genes are regulated by peroxisome proliferator-activated receptor alpha and gamma activators in a tissue- and inducer-specific manner. J. Biol. Chem. 273, 16710-16714.

3. Tontonoz, P., Hu, E., Devine, J., Beale, E.G. \& Spiegelman, B.M. (1995) PPAR 22 regulates adipose expression of phosphoenolopyruvate carboxykinase gene. Mol. Cell Biol. 15, 351357.

4. Schoonjans, K., Watanabe, M., Suzuki, H., Mahfoudi, A., Krey, G., Wahli, W., Grimaldi, P., Staels, B., Yamamoto, T. \& Auwerx, J. (1995) Induction of the acyl-coenzyme A synthetase gene by fibrates and fatty acids is mediated by a peroxisome proliferator response element in the C promoter. J. Biol. Chem. 270, 19269-19276.

5. Rodriquez, J.C., Gil-Gomez, G., Hegardt, F.G. \& Haro, D. (1994) Peroxisome proliferator-activated receptor mediates induction of the mitochondrial 3-hydroxy-3-methylglutaryl-CoA synthase gene by fatty acids. J. Biol. Chem. 269, 18767-18772.

6. Ribon, V., Johnson, J.H., Camp, H.S. \& Saltiel, A.R. (1998) Thiazolidinediones and insulin resistance: Peroxisome proliferator-activated receptor gamma activation stimulates the expression of CAP gene. Proc. Natl. Acad. Sci. U.S.A. 95, 14751-14756.

7. Elstner, E., Muller, C., Koshizuka, K., Wiliamson, E.A., Park, D., Asou, H., Shintaku, P., Said, J.W., Heber, D. \& Koeffler, H.P. (1998) Ligands for peroxisome proliferator- activated receptor gamma and retinoic acid receptor inhibit growth and induce apoptosis of human breast cancer cells in vitro and in BNX mice. Proc. Natl. Acad. Sci. U.S.A. 95, 8806-8811.

8. Kubota, T., Koshizuka, K., Williamson, E.A., Asou, H., Said, J.W., Holden, S., Miyoshi, I. \& Foeffler, H.P. (1998) Ligand for peroxisome proliferator-activated receptor gamma (troglitazone) has potent antitumor effect against human prostate cancer both in vitro and in vivo. Cancer Res. 58, 3344-3352.

9. Sarraf, P., Mueller, E., Jones, D., King, F.J., De Angelo, D.J., Partridge, J.B., Holden, S.A., Chen, L.B., Singer, S., Fletcher, C. \& Spiegelman, B.M. (1998) Differentiation and reversal of malignant changes in colon cancer through PPAR $\gamma$. Nature Med. 4, 1046-1052.

10. Yoshimoto, T., Naruse, M., Shizume, H., Naruse, K., Tanabe, A., Tanaka, M., Tago, K., Irie, K., Muraki, T., Demura, H. \& Zardi, L. (1999) Vasculo-protective effects of insulin sensitizing agent pioglitazone in neointimal thickening and hypertensive vascular hypertrophy. Atherosclerosis 145, 333-340.

11. Folkman, J. (1995) Angiogenesis in cancer, vascular, rheumatoid and other diseases. Nature Med. 1, 27-31.

12. Schaper, W. \& Buschmann, I. (1999) VEGF and therapeutic opportunities in cardiovascular diseases. Curr. Opin. Biotechnol. 10, 541543.

13. Adamis, A.P., Miller, J.W., Bernal, M.T., D’Amico, D.J., Yeo, T.K. \& Yeo, K.T. (1994) Increased vascular endothelial growth factor levels in the vitreous of eyes with proliferative retinopathy. Am. J. Ophthalmol. 118, 445450 .

14. Aiello, L.P., Avery, R.L., Arring, P.G., Keyt, B.A., Jampel, H.D., Shah, S.T., Pasquale, L.R., Thieme, H., Iwamoto, M.A., Park, J.E., Nguyen, M.S., Aiello, L.M., Ferrara, N. \& King, G.L. (1994) Vascular endothelial growth factor in ocular fluid of patients with diabetic retinopathy and other disorders. N. Engl. J. Med. 331, 1480-1487. 
15. Malecaze, F., Favard, C., Simorre-Pinatel, V., Mathis, A., Chollet, P., Favard, C., Bayard, F. \& Plouet, J. (1994) Detection of vascular endothelial growth factor messenger RNA and vascular endothelial growth factor-like activity in proliferative diabetic retinopathy. Arch. Ophthal. 112, 1476-1482.

16. Pe'er, J., Shweiki, D., Itin, A., Hemo, I., Gnessin, H. \& Keshet, E. (1995) Hypoxia-induced expression of vascular endothelial growth factor by retinal cells is a common factor in neovascularizing ocular diseases. Lab. Invest. 72, 638-645.

17. Aiello, L.P., Pierce, E.A., Foley, E.D., Takagi, H., Chen, H., Riddle, L., Ferrara, N., King, G.L. \& Smith, L.E.H. (1995) Suppression of retinal neovascularization in vivo by inhibition of vascular endothelial growth factor (VEGF) using soluble VEGF-receptor chimeric proteins. Proc. Natl. Acad. Sci. U.S.A. 92, 10457-10461.

18. Robinson, G.S., Pierce, E.A., Rook, S.L., Foley, E., Webb, R. \& Smith, L.E.S. (1996) Oligodeoxynucleotides inhibit retinal neovascularization in a murine model of proliferative retinopathy. Proc. Natl. Acad. Sci. U.S.A. 93, $4851-4856$

19. Adamis, A.P., Shima, D.T., Tolentino, M.J., Gragoudas, E.S., Ferrara, N., Folkman, J., D’Amore, P.A. \& Miller, J.W. (1996) Inhibition of vascular endothelial growth factor prevents retinal ischemia-associated iris neovascularization. Arch. Ophthalmol. 114, 66-71.

20. Okamoto, N., Tobe, T., Hackett, S.F., Ozaki, H., Vinores, M., LaRochelle, W., Zack, D.J. \& Campochiaro, P.A. (1997) Transgenic mice with increased expression of vascular endothelial growth factor in the retina. A new model of intraretinal and subretinal neovascularization. Am. J. Pathol. 151, 281-291.

21. Xin, X., Suya, Y., Kowalski, J. \& Gerristen, M.E. (1999) Peroxisome proliferator-activated receptor- $\gamma$ ligands are potent inhibitors of angiogenesis in vitro and in vivo. J. Biol. Chem. 274, 916-921.

22. Bishop-Bailey, D. \& Hla, T. (1999) Endothelial cell apoptosis induced by the peroxisome proliferator-activated receptor (PPAR) ligand 15-deoxy-delta12, 14-prostaglandin J2. J. Biol. Chem. 274, 17042-17048.

23. Chomczynski, P. \& Sacchi, N. (1987) Single step method of RNA isolation by acid guanidinum thiocyanate-phenol-chlorophorm extraction. Anal. Biochem. 162, 156-159.

24. Yu, K., Bayona, W., Kallens, C.B., Harding, H.P., Ravera, C.P., McMahon, G., Brown, M., \& Lazar, M.A. (1995) Differential activation of peroxisome proliferator-activated receptors by eicosanoids. J. Biol. Chem. 270, 2397523983.

25. Yamakawa, K., Hosoi, M., Koyama, H., Tanaka, S., Fukumoto, S., Morii, H., \& Nishizawa, Y. (2000) Peroxisome proliferator-activated receptor-gamma agonists increase vascular endothelial growth factor expression in human vascular smooth muscle cell. Biochem. Biophys. Res. Commun. 271, 571- 574.

26. Bamba, H., Ota, S., Kato, A., Kawamoto, C., Fujiwara, K. (2000) Prostaglandins up-regulate vascular endothelial growth factor production through distinct pathways in differentiated U937 cells. Biochem. Biophys. Res. Commun. 273, 485-491.

27. Tontonoz, P., Nagy, L., Alvarez, J.G., Thomazy, V.A., Evans, R.M. (1998) PPAR $\gamma$ promotes monocyte/macrophage differentiation and uptake of oxidized LDL. Cell 93, 241-252.

28. Ricote, M., Huang, J., Fajas, L., Li, A., Welch, J., Najib, J., Witzum, J.L., Auwerx, J., Palinski, W. \& Glass, C.K. (1998) Expression of the peroxisome proliferator-activated receptor gamma (PPAR $\gamma$ ) in human atherosclerosis and regulation in macrophages by colony stimulating factors and oxidized LDL. Proc. Natl. Acad. Sci. U.S.A. 95, 7614-7619. 
29. Steals, B., Koenig, W., Habib, A., Merval, R., Lebret, M., Torra, I.P., Delerive, P., Fadel, A., Chinetti, G., Fruchard, J.C., Najib, J., Maclouf, J. \& Tedgui, A. (1998) Activation of human aortic smooth muscle cells is inhibited by PPAR $\alpha$ but not by PPAR $\gamma$ activators. $N a$ ture 393, 790-793.

30. Iijima, K., Yoshizumi, M., Ako, J., Eto, M., Kim, S., Hashimoto, M., Sugimoto, N., Liang, Y.Q., Sudoh, N., Toba, K. \& Ouchi, Y. (1998) Expression of peroxisome proliferator-activated receptor- $\gamma(\mathrm{PPAR} \gamma)$ in rat aortic smooth muscle cells. Biochem. Biophys. Res. Commun. 247, 353-356.

31. Pasceri, V., Wu, H.D., Willerson, J.T. \& Yeh, E.T.H. (2000) Modulation of vascular inflammation in vitro and in vivo by peroxisome proliferator-activated receptor- $\gamma$ activator. Circulation 101, 235-240.

32. Ricote, M., Li, A.C., Willson, T.M., Kelly, C.J. \& Glass, C.K. (1998) The peroxisome proliferator-activated receptor gamma is a negative regulator of macrophage activation. Nature 391, 79-82.

33. Jiang, C., Ting, A.T. \& Seed, B. (1998) PPAR $\gamma$ agonists inhibit production of monocyte inflammatory cytokines. Nature 391, 82-86.

34. Momoi, A., Murao, K., Imachi, H., Yoshitaka, S., Nakamura, H., Hosokawa, H., Sato, M., Fujita, J., Okada, H., Ishida, T. \& Takahara, J. (1999) Thiazolidinedione inhibits production of RANTES in cytokine-treated human lung epithelial cell line. FEBS Lett. 452, 301-304.

35. Murao, K., Imachi, H., Atsuko, M., Sayo, Y., Hosokawa, H., Sato, M., Ishida, T. \& Takahara, J. (1999) Thiazolidinedione inhibits the production of monocyte chemoattractant protein-1 in cytokine-treated human vascular endothelial cells. FEBS Lett. 454, 27-30.

36. Law, R.E., Meehan, W.P., Xi, X.P., Graf, K., Wuthrich, D.A., Coats, W., Faxon, D. \& Hsueh, W.A. (1996) Troglitazone inhibits vas- cular smooth muscle cell growth and intimal hyperplasia. J. Clin. Invest. 98, 1897-1905.

37. Kihara, S., Ouchi, N., Funahashi, T., Shinohara, E., Tamura, R., Yamashita, S. \& Matsuzawa, Y. (1998) Troglitazone enhances glucose uptake and inhibits mitogen-activated protein kinase in human aortic smooth muscle cells. Atherosclerosis 136, 163-168.

38. Papapetropoulos, A., Garcia-Cardena, G., Madri, J.A. \& Sessa, W.C. (1997) Nitric oxide production contributes to the angiogenic properties of vascular endothelial growth factor in human endothelial cells. J. Clin. Invest. 100, 3131-3139.

39. Parenti, A., Mordibelli, L., Cui, X.L., Douglas, J.G., Hood, J.D., Granger, H.J., Ledda, F. \& Ziche, M. (1998) Nitric oxide is a upstream signal of vascular endothelial growth factor-induced extracellular signal-regulated kinase-1/ 2 activation in postcapillary endothelium. $J$. Biol. Chem. 273, 4220-4226.

40.Satoh, H., Tsukamoto, K., Hashimoto, Y., Hashimoto, N., Togo, M., Hara, M., Maekawa, H., Isoo, N., Kimura, S. \& Watanabe, T. (1999) Thiazolidinediones suppress endothelin-1 secretion from bovine endothelial cells: A new possible role of PPAR $\gamma$ on vascular endothelial function. Biochem. Biophys. Res. Commun. 254, 757-763.

41. Delerive, P., Martin-Nizard, F., Chinetti, G., Trottein, F., Fruchard, J.C., Najib, J., Duriez, P. \& Steals, B. (1999) Peroxisome proliferatoractivated receptor activators inhibit thrombininduced endothelin-1 production in human vascular endothelial cells by inhibiting the activator protein-1 signaling pathway. Circ. Res. 85, 394-402.

42. Aiello, L.P. (1997) Vascular endothelial growth factor and the eye: Biochemical mechanisms of action and implications for novel therapies. Ophthalmic Res. 29, 345-362.

43. Hammes, H.P., Lin, J., Bretzel, R.G., Brownle, M. \& Breier, G. (1998) Upregulation of the vas- 
cular endothelial growth factor/vascular endothelial growth factor receptor system in experimental background diabetic retinopathy of the rat. Diabetes 47, 401-406.

44. Kimura, H., Weisz, A., Karashima, Y., Hashimoto, K., Ogura, T., D’Acqusto, F., Addeo, R., Makuchi, M. \& Esumi, H. (2000) Hypoxia reponse element of the human vascular endothelial growth factor gene mediates transcriptional regulation by nitric oxide: Control of hypoxia - inducible factor-1 activity by nitric oxide. Blood 95, 189-197.

45. Finkenzeller, G., Sparacio, A., Technau, A., Marme, D. \& Siemeister, G. (1997) SP1 recognition sites in the proximal promoter of the human vascular endothelial growth factor gene are essential for platelet derived growth factor-induced gene expression. Oncogene 15, 669-676.

46. Ryuto, M., Ono, M., Izumi, H., Yoshida, S., Weich, H.A., Kohna, K. \& Kuwano, M. (1996) Induction of vascular endothelial growth factor by tumor necrosis factor alpha in human glioma cells. Possible roles of SP-1. J. Biol. Chem. 271, 28220-28228.

47. Krey, G., Mahfoudi, A. \& Wahli, W. (1995) Functional interactions of peroxisome proliferator-activated receptor, retinoid X-receptor, and SP1 in the transcriptional regulation of the acyl-coenzyme A oxidase promoter. Mol. Endocrinol. 9, 19-31.

48. Missbach, M., Jagher, B., Siga, I., Nayeri, S., Carlberg, C. \& Wiesenberg, I. (1996) Thiazo- lidine diones specific ligands of the nuclear receptor retinoid $\mathrm{Z}$ receptor/retinoid acid receptor-related orphan receptor alpha with potent antiarthritic activity. J. Biol. Chem. 271, 13515-13522.

49. Winrow, C.J., Capone, J.P. \& Rachubinski, R.A. (1998) Cross-talk between orphan nuclear hormone receptor $\mathrm{RZR} \alpha$ and peroxisome activated-receptor alpha in regulation of the peroxisome hydratase-dehydrogenase gene. $J$. Biol. Chem. 273, 31442-31448.

50. Kitamura, Y., Kakimura, J., Matsuoka, Y., Nomura, Y., Gebicke-Haerter, P.J. \& Taniguchi, T. (1999) Activators of peroxisome proliferator-activated receptor- $\gamma(\operatorname{PPAR} \gamma)$ inhibit inducible nitric oxide synthase expression but increase heme oxygenase-1 expression in rat glial cells. Neurosci. Lett. 262, 129-132.

51. Jozkowicz, A., Placha, W., Krzesz, R., Dulak, J. \& Dembinska-Kiec, A. (2000) Effect of linoleic acid on the expression of nitric oxide synthase and heme oxygenase- 1 in rat vascular smooth muscle cells;in Advances in Lipoprotein and Atherosclerosis Research. Proc. 10th International Dresden Symposium on Lipoprotein and Atherosclerosis, in press.

52. Dulak, J., Jozkowicz, A., Foresti, R., Green, C. \& Motterlini, R. (1999) Regulation of VEGF synthesis in vascular smooth muscle cells by carbon monoxide and nitric oxide metabolic pathways. Angiogenesis and Tumors, pp. 22-25, October 1999, Paris, France. Abstract. 